Aleksander Cywiński*

ORCID: 0000-0002-3945-9607

Szczecin, Poland

\title{
Solitude of the United Kingdom towards Europe - Notes from my Diary
}

\section{Samotność Zjednoczonego Królestwa wobec Europy - notatki z mojego pamiętnika}

\begin{abstract}
Referring to autoethnography, I contemplate the consequences of Brexit in the individual dimension. I do not consider this process as affecting only the life of UK citizens; rather, I treat Brexit as an impulse to form the concept of solitude policy.
\end{abstract}

Key words: Community; United Kingdom; Brexit; solitude; dialogue.

Streszczenie: Odwołując się do autoetnografii, zastanawiam się nad konsekwencjami Brexitu w wymiarze indywidualnym. Nie uważam tego procesu za mający wpływ na życie jedynie mieszkańców Wielkiej Brytanii. Traktuję Brexit jako asumpt do sformowania koncepcji polityki samotności.

Słowa kluczowe: Wspólnota; Zjednoczone Królestwo; Brexit; samotność; dialog.

* Dr. Aleksander Cywiński, Pedagogy Institute, University of Szczecin, email: aleksander. cywinski@usz.edu.pl. 


\section{Introduction}

Let me briefly introduce myself. I have always been fascinated by British culture. British popular music is the love of my life; I also love British movies. And what I found great in this culture, I have transferred to other spheres of life, including politics. Another aspect, and perhaps the most important issue for me, was learning English. At primary school, my class was one of the first to have switched from learning Russian to learning English. This had a symbolic dimension: in the early 1990s, it was an unambiguous declaration that we were in favour of English culture.

The island seemed an oasis of peace, stability and reason. But we live in the world of VUCA (Gläse, 2018) - volatility, uncertainty, complexity and ambiguity - so nothing can last forever. As Bob Dylan sang, The Times They Are A-Changin'; for me, Brexit is an example of this. Moreover, it is another proof of the correctness of Bauman's concept of liquid modernity (Bauman, 2000).

In my opinion, one of the reasons why the Poles wanted to join the EU was because the UK was already part of it; Britain appeared to be an island of stability, certainty, simplicity and unambiguity. This is my introduction to my considerations regarding the solitude of the UK in relation to Europe. I remember perfectly well that in the symbolic sense, both learning English and moving towards a united Europe were expected to promote individual and general well-being (Wilk, 2014). But now we have reached the next level in our shared experience of history. But, unfortunately, it is more serious than a computer game.

My question is: What does Brexit teach me in post-truth times? These are times in which emotions are sovereign, and the only certain thing is change. Therefore, I give voice to my emotions. While preparing for 'Alone Together' - our international pan-disciplinary symposium on solitude in community (York, April 2019) - I decided to keep a diary throughout February, in which I would note my comments on Brexit. It is the feelings contained in the diary that are my main catalyst for treating this topic in such a way.

Why February, and not March? Because I had predicted that in February everything would be settled; that all matters related to Brexit would be completed. As you know, I was wrong. Now it seems to me that I was naive, and that the worst is ahead of us. We are probably heading towards the UK's final exit from the EU (I'm writing this at the end of January 2020); but to 
use sports terminology, the ball is still in the game, and it is and will be an extremely brutal game.

In my text, I would like to propose two stages of analysis: the first, in which I refer to my diary entries; and the second, in which I refer to the concept of solitude in politics. I would like to emphasise that my paradigm (worldview) is shaped by belief in the significance of community, and in the positive impact of collective actions on development in all spheres of social life, including upbringing and education. This is my justification for taking up the indicated topic in Paedagogia Christiana, a journal which deals with contemporary conditions of human education.

In addition, I choose not to present the events in chronological order. Brexit, understood as the process of the UK leaving the EU, is happening right in front of our eyes, and there is no need to list all its stages in precise detail.

\section{Background, or why I decided to use autoethnography}

I decided to use autoethnography because I consider it relevant to the subject. Arthur P. Bochner points out:

We autoethnographers believe that research on human life should be oriented not only toward facts but also toward meanings; not only under the rules of scientific rigor, but also under the inspiration of moral imagination; not only for the purpose of attaining better predictions and more control, but also to achieve peace of mind and to alleviate injustice and suffering; not only from the stance of neutrality and distance, but also from the position of caring and vulnerability; not only for the purpose of producing conventional, received texts, but also with the goal of performing evocative, creative, and dialogic expressions of lived experiences. (Bochner, 2017, p. 78)

Such thinking liberates. It justifies spontaneous writing. It legitimises keeping a diary and then using it for scientific purposes - in order to be able to research human life.

The following recommendations are a development of the above:

Our understanding of others can only proceed from within our own experience, and this experience involves our lived histories.... We come to know others through ourselves, but also to know ourselves by knowing others. ... Autoeth- 
nography appeals to the conscience of the human sciences, offering an ethical design for a social science of meanings, sense making, social justice, and bodily experience. ... This means not coloring over lived experiences with concepts organised into systems of thought of interest to elite researchers but of little relevance to wounded or marginalized people. ... Greater self-awareness and self-reflexivity are both the gifts and the afflictions of autoethnography ... . (ibidem, pp. 69-71)

I would particularly like to emphasise the transition from the individual to the public sphere:

Autoethnography is not only a work of memory; it is also a work of narrative. ... Autoethnographers must recount what they remember, retelling events and experiences usually in the form of a written, spoken, or performed story.... The truths of autoethnography exist between storyteller and story listener. ... Autoethnographies move events and situations of private interest into the public domain. ... Autoethnography is a genre of doubt. In practice, autoethnography is not so much a methodology as it is a way of life, one that acknowledges contingency; finitude; embeddedness in storied being; openness to otherness; dedication to justice, ethics, and moral imagination; and a desire for edification to keep the conversation going. ... To be alive is to be uncertain. (ibidem, pp. 73-77)

A characteristic feature of autoethnography is a situation in which the roles of the researcher and respondent are entrusted to one person (Jagieła, 2015, p. 35; Urbańska, 2012, p. 35). The purpose of such a solution, adapting Anglo-Saxon models, was aptly expressed by Oskar Szwabowski:

Preserving experiences, learning through experience, reconstructing experience, developing reflectiveness and empathy, immersing in tides are ways to know, understand and process, and to interact. An attempt to understand yourself, others, relationships. Creating a space for discussion and self-development. ... I see in it [autoethnography] the possibility of self-development. (Szwabowski, 2019, p. 100)

These words seem to be in line with the postulates of Carolyn S. Ellis and Arthur P. Bochner, claiming that autoethnography is not an objection against traditionally perceived science, but another way of trying to understand social processes (Ellis \& Bochner, 2006, p. 443). I chose the above 
quotations not only based on their substantive value - for my intellectual development - but also because of their emotional charge, which was like that which accompanied me when writing the diary. This emotionality manifests itself in my statement that I would like to have been the author of the above quotes.

\section{Action, or what I experienced}

I remember that when I was writing the diary, I was tired and irritable (because of the workload), but also mindful. This means that although they were not long entries, I consider them valuable. I usually made entries late in the evening, after a full day's work.

First of all, I would like to point out that, under the influence of Brexit, I began to identify myself as a Europophile - that is, someone who is a devotee of what is European or favours participation in the European Union. It started at the very beginning of my examination of the subject. Incidentally, I discovered that the word 'Europophile' is not in the Polish dictionary, while there is, for example, a 'Rusophile' (a supporter and enthusiast of what is Russian) or 'Germanophile'. Noticing this attitude (identifying myself as a Europophile) is my first, and perhaps the most important, discovery from writing a diary. It's a process where I notice something only when I see a change.

When analysing my entries, I noticed that they related to the relationship between politics and emotions. Here are examples which, according to Arthur P. Bochner's postulate, are the inspiration of moral imagination (Bochner, 2017):

- entry from 05/02/2019:

And maybe they are experiencing this rebellion for us, against something that seems distant and imposed? And paradoxically, maybe it will save the EU? Brexit as a cold shower for everyone, something that makes us think. Maybe this is the role of the island?,

- entry from 08/02/2019:

Maybe such a breakup is like between people, lovers, spouses? Sometimes calm, by mutual consent, and sometimes with a fight. Tusk said something about hell. Emotions begin to emerge. It turns out that this is not parting in peace. Will we hear grievances in the near future? About who owes or has lost what to whom? 
Probably so. This metaphor of lovers again leads to the concept that the island and Europe are like people.

Other examples are oriented towards meanings (not facts) (ibidem, 2017):

- entry from 13/02/2019:

What has Brexit taught me so far? Maybe nothing is permanent. Even agreements in such large structures as the EU. And that you can relate what happens in politics, to what happens in private and personal life. I cannot help it, but in my opinion, there is chaos in this stable country. I am writing the word 'chaos' and I'm thinking about the loneliness of the island in relation to Europe,

- entry from 18/02/2019:

What does PM Teresa May think about, when it is late, and she has a moment to rest?

My intention is not to fill the text with diary quotes. Indeed, I have quoted auto-ethnography researchers abundantly, but I would like to point out this is due to my admiration for their concept. Rather, I would like to focus on what Brexit has taught me. That I objectify - that is, I visualise - the subject of my analysis; this makes it comprehensible to me. The image I see is simple. There are the moving contours of the UK and Europe. I see, therefore, a map of our continent, where dynamic processes take place. But this tectonic movement is not the result of natural forces, but of human emotions. That's how I experience it. The metaphor for the island is a ship that is sailing away, but no one knows where she will arrive. The physical distance between London and Paris, Berlin or Warsaw does not change, but the distance changes in the mental sphere. The effects are therefore difficult to predict. I have been to London several times, and I can see the streets of this city getting further and further away from me. I emphasise that this is not a metaphor: in fact, there are walls rising between neighbours, members of the same community. I am aware that this sounds pompous and weird, but politicians seem to be acting like a team of bricklayers at work. Or, returning to the metaphor of a ship leaving the shore, politicians are sailors who sail with no concern about difficult circumstances - they sail on cheerfully while singing their song.

Due to this, Brexit teaches me also that it is naive to believe in the durability of the EU and in politicians' common sense. The scale of this phenom- 
enon is a shock to me. I am aware that a referendum took place (a decision of ordinary people), but at the same time it is difficult to resist the impression that voters were being manipulated by politicians (Cadwalladr, 2017). We truly live in the world of VUCA. Durability turned out to be a delusion. Just as much a delusion is faith in politicians, their rationality, their care for the interest of voters. In general, the only certain thing is that something unexpected is going to happen. That the future will provide us with surprises. It cannot be predicted. I recollect one of my trips to Europe, when I had gone to Romania and Bulgaria just before they joined the EU. My presence here is a journey (to the UK) in the other direction. I am surprised.

I am aware that connecting the two roles of researcher and responder may be risky - especially since the described situation is still taking place given that emotions may prevail; but it is still chance for self-development. Also, by expressing emotions, anarchist thoughts appear in my head. The crisis in Great Britain affects how I perceive the Polish political scene. Divisions and disagreements make me think about our leaders, generally, not as statesmen, but as participants in constant fun. People who are also having fun at my expense. That's how I started to see politicians: fighting for power, and all the time trying to tell us that they are fighting for truth. In this context, the high price of the ironic painting Devolved Parliament by Banksy - a work of art that criticises the political class - doesn't surprise me (Reyburn, 2019).

I will end this part with poetry; specifically, the first thought that came to my mind when I learned the title of the conference ('Alone Together'). It reminded me of the beautiful song by the band Crowded House, 'Together Alone'. This is a unique combination of rock music and the Moorish tradition. The words of this song go as follows:

Together alone

Above and beneath

We were as close

As anyone can be

Now you are gone

Far away from me. (Crowded House, 1993)

The song is probably about love and death; Eros and Tanatos. An eternal, divine life cycle. So, we have a mystical lyric. Of course, I have other associations; these are caused by political events related to Brexit, the separation of the EU and the UK. Well, our present influences our understanding of cultural texts. In conclusion, I want to say that the process of Brexit seems 
unimaginable from the point of view of a 40-year-old resident of Szczecin, a city in Central Eastern Europe, in a post-communist state like Poland. I am interested not only in the solitude of individual people, but - perhaps more that of whole communities, nations and states. In this case, solitude of the UK towards Europe, I think that Brexit is not only a matter for the inhabitants of the Island, just as solitude does not only affect the person who experiences it.

I would like to sum up this part of the discussion as best I can. I admit that I am a bit helpless (I am writing these words on February 1, 2020). So, I reach for the diary. Maybe there are some words there that were first the subject of analysis, but which are now suitable for performing meta-analysis. Words in which I look for raw information, and at the same time, words that explain everything else. A diary entry through which I induce, but which is also the nucleus of deductive reasoning.

The following entry catches my attention - the one which I made during my stay as part of the Erasmus programme at the Sankelmark Academy, at a workshop on the perception of a shared history:

- entry from 26/02/2019:

Two thoughts today about Brexit and I'm still at the international workshop. After a few days, after the initial integration, people strived to speak their own languages. And it worried me. But then the evening came, we were sitting in the bar and some remained in their own linguistic company, but some integrated again, went beyond nationality self-restrictions. It usually works like a pendulum. So Brexit had to happen, and it could have been the Netherlands, Portugal or Sweden. But it happened to the Island.

The integration process will deepen and paradoxically weaken at the same time. Thinking in black or white categories in politics is a mistake. At exactly the time I am writing these words, I recall Leo Tolstoy's War and Peace, with its main thesis: There are too many variables to predict, the world is too complex.

\section{What's going on - The politics of solitude}

In attempting to explain to myself the political process we are witnessing, I created the concept of solitude in politics; I then included Brexit in this scheme. This is my reflection, born of the autoethnographic practice of keeping a diary. 
The politics of solitude can be defined as activities performed by an entity that aims to isolate itself or another entity from the international community (i.e. with respect to other states or international organisations), and thus create a distance. Due to the fact that this solitude influences the functioning of individuals (psychological aspect) and communities (sociological aspect), it is not only an issue belonging to political science, which is understood as researching activities related to the exercise of political power.

The politics of solitude is a process which occurs in two model types:

1. Active model - based on the state isolating itself. In this model, processes directed inwards (social, ideological, cultural, economic and military activities) are aimed at isolating the state. Nowadays, isolation can only have a limited effect, and this seems to be most often the case; nevertheless, consequences can still stem from this.

2. Passive model - a state being isolated by other ones. Realisation of this model is based on influence being applied by external entities, towards the isolated one.

It is possible for a state to operate a policy of solitude in both described models. Although it never leads to breaking all ties that connect it with the world, nevertheless it is a process opposed to globalisation - which is understood as limiting the sovereignty and increasing the interdependence and integration of states (and consequently of societies, economies and cultures).

Brexit is an example of the active model. The UK's geographical position may influence the isolation process, as it can be said that islands have a predisposition to isolation (Great Britain in the context of Brexit). I must admit that an extreme form of solitude - leaving the EU without a trading agreement, or cutting ties connecting the island with Europe - could cause huge problems: 'Among them: fuel, food, and medicine shortages, rising costs of social care, significant port disruptions, and a hard border with Ireland' (Shendruk, 2019).

Both models (active and passive) can be further divided into subcategories: positive and negative. I have subjectively selected respect for human rights as a basis for this division. When assessing the models in question, it is helpful to refer to the Universal Declaration of Human Rights, which, although it is not universally binding, is a set of basics of rights:

- positive - does not take away rights resulting from the Declaration or policies intended to protect these rights (example: international community policy towards South Africa in the times of apartheid),

- negative - deprivation of human rights (example: China's policy towards Tibet). 
It is difficult to say unequivocally whether these negative expected consequences allow us to conclude (regarding Brexit) that we are dealing with a negative active solitude. If the economic and social consequences of Brexit lead to a weakening of respect for human rights, this will confirm that Brexit belongs to the 'negative active' category of solitude. However, if there is no violation of human rights, Brexit will be assigned to the 'positive active' category of solitude.

\section{Latest news:}

'Boris Johnson promises Brexit will lead to national revival' (Stewart, Boffey \& Syal, 2020).

Only questions, no answers.

... The ball is in play, so I have to make some assumptions. Referring to my worldview, I assume that the division will bring the aforementioned negative consequences.

It is true that my thinking is shaped in some way by the Holy Father Francis. According to the apostolic exhortation, Evangelii Gaudium:

The whole is greater than the part.

An innate tension also exists between globalisation and localisation. We need to pay attention to the global so as to avoid narrowness and banality. Yet we also need to look to the local, which keeps our feet on the ground. (Apostolic Exhortation Evangelii Gaudium Of The Holy Father Francis, 2013, [EG] 233, 234)

In my opinion, the worldview that the Pope presents is apt. The extension of the above words is a fragment of the Pope's address to the members of the diplomatic corps:

As a reaction to a 'spherical' notion of globalisation, one that levels differences and smooths out particularities, it is easy for forms of nationalism to re-emerge. Yet globalization can prove promising to the extent that it can be 'polyhedric', favouring a positive interplay between the identity of individual peoples and countries and globalisation itself, in accordance with the principle that the whole is greater than the part. (Francis, 2019)

These words are not the unconditional praise of globalisation. Globalisation is good when it allows small states to survive and maintain their indi- 
viduality. The European Union seems to be structured according to this postulate. Thus, based on my diary notes (autoethnography), solitude of the UK towards Europe - is on the one hand informative (it allowed me to formulate a concept of solitude in politics), yet it is also unexpected and disturbing.

\section{References}

Bauman, Z. (2000). Liquid Modernity. Cambridge: Polity Press.

Bochner, A. P. (2017). Heart of the Matter. A Mini-Manifesto for Autoethnography. International Review of Qualitative Research, 10(1), 67-80.

Cadwalladr, C. (2017). The great British Brexit robbery: how our democracy was hijacked. The Guardian, 20 May 2017. https://www.theguardian.com /technology/2017/may/07/the-great-british-brexit-robbery-hijacked-democracy (accessed 15.10.2019).

Crowded House (1993). Together Alone. Universal Music Group.

Francis (2013). Apostolic exhortation Evangelii Gaudium of The Holy Father Francis on the proclamation of the gospel in today's world. The Holy See.

Francis (2019). Address of his Holiness Pope Francis to the members of the diplomatic corps accredited to the holy see for the traditional exchange of new year greeting. The Holy See. http://w2.vatican.va/content/francesco/en/speeches/2019/january/documents/papa-francesco_20190107_corpo-diplomatico. $\mathrm{html}$ (accessed 19.10.2019).

Gläse, W. (2018). VUCA world. https://www.vuca-world.org/ (accessed 15.10.2019). Jagieła, J. (2015). Stownik terminów i pojęć badań jakościowych nad edukacją. Częstochowa: Akademia im. Jana Długosza w Częstochowie.

Ellis, C. S. \& Bochner, A. P. (2006). Analyzing Analytic Autoethnography. An Autopsy. Journal of Contemporary Etnography, 35(4), 429-449.

Reyburn, S. (2019). Banksy Painting 'Devolved Parliament' Sells for $\$ 12$ Million. The New York Times, 3 Oct. 2019. https://www.nytimes.com/2019/10/03/arts/ design/banksy-devolved-parliament-auction.html (accessed 15.10.2019).

Shendruk, A. (2019). Leaked Brexit document shows the UK government anticipates a no-deal, with dire consequences. Quartz, 18 August 2019. https://qz. com/1690012/brexit-document-shows-the-uk-anticipates-the-worst/ (accessed 18.10.2019).

Stewart, H., Boffey, D. \& Syal, R. (2020). Boris Johnson promises Brexit will lead to national revival. The Guardian, 31 Jan 2020. https://www.theguardian.com/ politics/2020/jan/31/boris-johnson-promises-brexit-will-lead-to-national-revival (accessed 01.02.2020). 
Szwabowski, O. (2019). Nekrofilna produkcja akademicka i pieśni partyzantów. Wrocław: Instytut Pedagogiki Uniwersytetu Wrocławskiego.

Urbańska, S. (2012). Autoetnografia. In K. T. Konecki \& P. Chomczyński (eds.),

Slownik socjologii jakościowej (pp. 34-39). Warszawa: Difin.

Wilk, P. (2014). Znaki szczególne. Warszawa: Wydawnictwo Literackie. 